This is an electronic reprint of the original article. This reprint may differ from the original in pagination and typographic detail. Author(s): Lips, Felicitas; Fettinger, James C.; Mansikkamäki, Akseli; Tuononen, Heikki; Power,
Philip

Title: Reversible Complexation of Ethylene by a Silylene under Ambient Conditions

Year: $\quad 2014$

Version:

Please cite the original version:

Lips, F., Fettinger, J. C., Mansikkamäki, A., Tuononen, H., \& Power, P. (2014).

Reversible Complexation of Ethylene by a Silylene under Ambient Conditions. Journal of the American Chemical Society, 136(2), 634-637.

https://doi.org/10.1021/ja411951y

All material supplied via JYX is protected by copyright and other intellectual property rights, and duplication or sale of all or part of any of the repository collections is not permitted, except that material may be duplicated by you for your research use or educational purposes in electronic or print form. You must obtain permission for any other use. Electronic or print copies may not be offered, whether for sale or otherwise to anyone who is not an authorised user. 


\title{
Reversible Complexation of Ethylene by a Silylene under Ambient Conditions
}

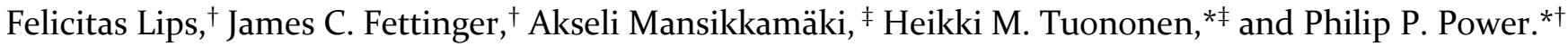 \\ † Department of Chemistry, University of California, One Shields Avenue, Davis, CA 95616. \\ ‡ Department of Chemistry, University of Jyväskylä, P.O. Box 35, FI-40014 Jyväskylä, Finland.
}

\begin{abstract}
Treatment of toluene solutions of the silylenes $\mathrm{Si}\left(\mathrm{SAr}^{\mathrm{Me}_{6}}\right)_{2}\left(\mathrm{Ar}^{\mathrm{Me}} 6=\mathrm{C}_{6} \mathrm{H}_{3}-2,6\left(\mathrm{C}_{6} \mathrm{H}_{2}-2,4,6-\right.\right.$ $\left.\left.\mathrm{Me}_{3}\right), \mathbf{1}\right)$ or $\mathrm{Si}\left(\mathrm{SAr}^{\mathrm{Pr}_{4}^{\mathrm{i}}}\right)_{2}\left(\mathrm{Ar}^{\mathrm{Pr}^{\mathrm{i}}}{ }_{4}=\mathrm{C}_{6} \mathrm{H}_{3}-2,6\left(\mathrm{C}_{6} \mathrm{H}_{3}-2,6-\right.\right.$ $\left.\left.\operatorname{Pr}_{2}{ }_{2}\right), 2\right)$ with excess ethylene gas affords the siliranes $\left.\left(\mathrm{Ar}^{\mathrm{Me}} 6\right)_{2}\right)_{2} \mathrm{SiCH}_{2} \mathrm{CH}_{2}(3)$ and $\left(\mathrm{Ar}^{\mathrm{Pr}_{4}^{\mathrm{i}}}{ }_{4}\right)_{2} \mathrm{SiCH}_{2} \mathrm{CH}_{2}(4)$.

Silirane $\mathbf{4}$ evolves ethylene spontaneously at room temperature. A Van't Hoff analysis by variable temperature ${ }^{1} \mathrm{H}$ NMR spectroscopy showed that $\Delta \mathrm{G}_{\text {assn }}$ is $-24.9(2.5) \mathrm{kJ} \mathrm{mol}^{-1}$ for 4 . A computational study of the reaction mechanism using a model silylene $\mathrm{Si}(\mathrm{SPh})_{2}\left(\mathrm{Ph}=\mathrm{C}_{6} \mathrm{H}_{5}\right)$ was in harmony with the Van't Hoff analysis and yields $\Delta \mathrm{G}_{\text {assn }}=-24 \mathrm{~kJ} \mathrm{~mol}^{-}$ ${ }^{1}$ and an activation energy $\Delta \mathrm{G}^{\ddagger}$ of $54 \mathrm{~kJ} \mathrm{~mol}^{-1}$.
\end{abstract}

The reactions of silylenes with unsaturated carbon-carbon bonded molecules have been studied extensively because of their fundamental nature and their importance for the synthesis of small siliconcontaining rings. ${ }^{1}$ Several groups have shown that transient silylenes generated either photochemically or via reduction of precursor diorganosilicon(IV)dihalides afforded silirane products in a stereospecific manner and in agreement with the singlet ground state of the silylene. ${ }^{2}$ However, the reverse reaction to regenerate the silylene with olefin elimination can only be observed at higher temperatures. In general, reversible reactions between olefins and main group molecules are rare. The only currently published examples (Scheme 1) involve reversible cyclization of ethylene or norbornadiene with the distannynes $\mathrm{Ar}^{\mathrm{Pr}^{\mathrm{i}}}{ }_{4} \mathrm{SnSnAr} r^{\mathrm{Pr}^{\mathrm{i}}}{ }_{4}$ and $\mathrm{Ar}^{\mathrm{Pr}^{\mathrm{i}} 8 \mathrm{SnSnAr}}{ }^{\mathrm{Pr}_{8}{ }_{8}}\left(\mathrm{Ar}^{\mathrm{Pr}^{\mathrm{i}}}{ }_{4}=\mathrm{C}_{6} \mathrm{H}_{3}-\right.$ 2,6 $\left(\mathrm{C}_{6} \mathrm{H}_{3}-2,6-\mathrm{Pr}_{2}^{\mathrm{i}}\right)_{2} ; \mathrm{Ar}^{\mathrm{Pr}^{\mathrm{i}} 8}=\mathrm{C}_{6} \mathrm{H}-2,6\left(\mathrm{C}_{6} \mathrm{H}_{2}-2,4,6-\right.$ $\left.\left.\operatorname{Pr}_{3}{ }_{3}\right)_{2}-3,5-\operatorname{Pr}_{2}\right)^{3}$ to generate the $1,4^{-}$ distannabicyclo[2.2.0]butanes, as exemplified in Scheme 1 (1), or the reversible binding of ethylene by the silylene-phosphine complex (also described as a phosphonium sila-ylide), as shown in Scheme 1 (2), to give the corresponding silirane product with a penta-coordinate silicon atom. ${ }^{4}$

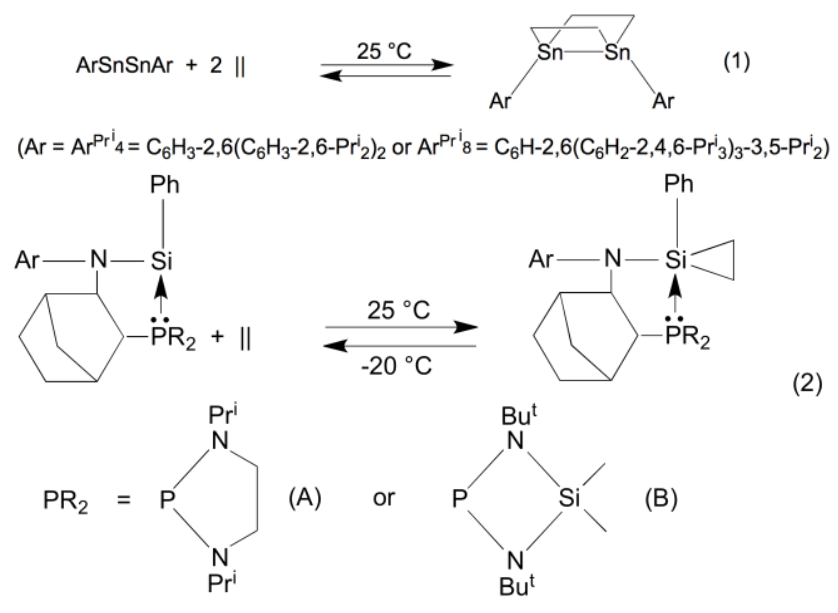

Scheme 1. Illustration of reversible reactions of main group compounds with ethylene near room temperature.

The stability of the product was found to be strongly related to the nucleophilic character of the phosphine ligand and irreversible binding was observed when $\mathrm{PR}_{2}=\mathrm{PPh}_{2}$. Herein, we report on the first examples of reversible ethylene binding by stable, two-coordinate silylenes. We demonstrate that $\mathrm{Si}\left(\mathrm{SAr}^{\mathrm{Me}}\right)_{2}\left(\mathrm{Ar}^{\mathrm{Me}_{6}}=\mathrm{C}_{6} \mathrm{H}_{3}-2,6\left(\mathrm{C}_{6} \mathrm{H}_{2}-2,4,6-\mathrm{Me}_{3}\right)_{2}\right)$, 1) 5 and $\mathrm{Si}\left(\mathrm{SAr}^{\mathrm{Pr}^{\mathrm{i}}}{ }_{4}\right)_{2}\left(\mathrm{Ar}^{\mathrm{Pr}^{\mathrm{i}}}{ }_{4}=\mathrm{C}_{6} \mathrm{H}_{3}-2,6\left(\mathrm{C}_{6} \mathrm{H}_{3}-2,6-\mathrm{Pr}_{2}\right)_{2}\right.$, 2) ${ }^{6}$ react reversibly with ethylene at room temperature, and show that the reaction is strongly affected by the steric properties of the silylene and olefin type. 
Exposure of toluene solutions of 1 or 2 to ethylene gas under anaerobic and anhydrous conditions results in a discharge of the yellow color of $\mathbf{1}$ (within a few seconds) or $\mathbf{2}$ (within one minute), and the formation of the siliranes 3 and 4 as shown in Scheme 2.

$$
\begin{aligned}
& (\mathrm{ArS})_{2} \mathrm{Si}:+11 \\
& 1 \text { or } 2 \\
& \underset{\text { PhMe }}{\stackrel{\mathrm{Phm} \text { temperature }}{\longrightarrow}} \\
& \mathrm{Ar}=\mathrm{C}_{6} \mathrm{H}_{3}-2,6\left(\mathrm{C}_{6} \mathrm{H}_{2}-2,4,6-\mathrm{Me}_{3}\right)_{2} \text { (1 or 3) } \\
& \mathrm{Ar}=\mathrm{C}_{6} \mathrm{H}_{3}-2,6\left(\mathrm{C}_{6} \mathrm{H}_{3}-2,6-\mathrm{Pr}_{2}\right)_{2} \text { (2 or 4) }
\end{aligned}
$$

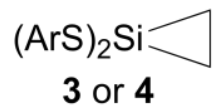

Scheme 2. Equilibrium reactions for compounds 1 and 2 with ethylene in toluene at ambient temperature to form the siliranes 3 and 4 .

The products were characterized by ${ }^{1} \mathrm{H},{ }^{13} \mathrm{C}\left\{{ }^{1} \mathrm{H}\right\}$, and ${ }^{29}$ Si NMR spectroscopy ( 3 and 4 ), and by X-ray crystallography (4). The ${ }^{29} \mathrm{Si}$ NMR spectra of 3 and 4 in $d^{8}$-toluene reveal an upfield signal at $-44.08 \mathrm{ppm}$ (3) and $-42.22 \mathrm{ppm}$ (4) that display splitting into a quintet pattern with a 1:4:6:4:1 intensity ratio owing to coupling to the hydrogens of the bound ethylene. The ${ }^{29} \mathrm{Si}^{1}{ }^{1} \mathrm{H}$ coupling constant is $5.62(3)$ and $5.89 \mathrm{~Hz}$ (4). The ${ }^{29} \mathrm{Si}$ NMR spectrum of 4 also displays a signal at $+270.7 \mathrm{ppm}$, due to free silylene $2,{ }^{6}$ owing to the existence of a dissociation equilibrium in solution. The ${ }^{1} \mathrm{H}$ NMR spectrum 4 in $d^{8}$-toluene solutions display signals at $5.25 \mathrm{ppm}$ due to uncomplexed ethylene and at 0.64 (3) and $0.4 \mathrm{ppm}$ (4) due to bound ethylene in addition to the signals of the arylthiolate substituents. A Van't Hoff analysis of the association of ethylene with $\mathbf{2}$ using variable temperature ${ }^{1} \mathrm{H}$ NMR spectroscopy afforded a $\Delta \mathrm{H}_{\text {assn }}$ of $-83.61(8.4) \mathrm{kJ} \mathrm{mol}^{-1}$, and a $\Delta \mathrm{G}_{\text {assn }}=-24.9$ (2.5) kJ $\mathrm{mol}^{-1}$ at $300 \mathrm{~K}$, which is somewhat more favorable than the $c a .-3 \mathrm{~kJ} \mathrm{~mol}^{-1}$ reported for the reaction in Scheme 1 (2) with the phosphine group A. ${ }^{4}$ A Van't Hoff analysis of the association of ethylene with $\mathbf{1}$ using an ethylene-saturated solution up to $343 \mathrm{~K}$ has not been possible to date due to the solubility characteristics of $\mathbf{1}$ and $\mathbf{3}$.

The structural details of 4 were determined by X-ray crystallography, and are illustrated by the structure of 4 shown in Figure 1. It can be seen that the silicon atom is four-coordinate, being complexed to two sulfur and two carbon atoms with very distorted silicon coordination geometry (cf. C-Si-C = $50.75(9)^{\circ}$; S-Si-S = 117.84(3) ${ }^{\circ}$ ). The S-Si-S angle is over $30^{\circ}$ wider than the $85.08(5)^{\circ}$ observed in the precursor silylene 2. ${ }^{6}$ The Si-S distance $(2.1179(7) \AA \AA$ in 4) is slightly shorter than those (2.158(3) $\AA$ in 1 and 2.137(1) $\AA$ in 2) in the free silylenes, ${ }^{5,6}$ and the $\mathrm{Si}-\mathrm{C}$ bond length, $1.829(2) \AA$, is similar to those in other siliranes. ${ }^{2 c, 4,7}$ The $C-C$ bond length within the silirane ring $(1.560(3) \AA$ ) is consistent with single C-C bonding, and is similar to those in previously reported silirane structures. ${ }^{4,7}$ The silylene $\mathbf{1}$ also reacts readily with excess norbornadiene (NBD) to generate a silirane 5 with a similar $\mathrm{SiS}_{2} \mathrm{C}$ core geometry to 3 , in which one of the double bonds of NBD has reacted with the silicon atom in $\mathbf{1}$ (see Supporting Information). This reaction, however, is irreversible up to $162{ }^{\circ} \mathrm{C}$, at which temperature 5 decomposes. No reaction was observed between 2 and NBD (probably for steric reasons), even when they were refluxed together in toluene.

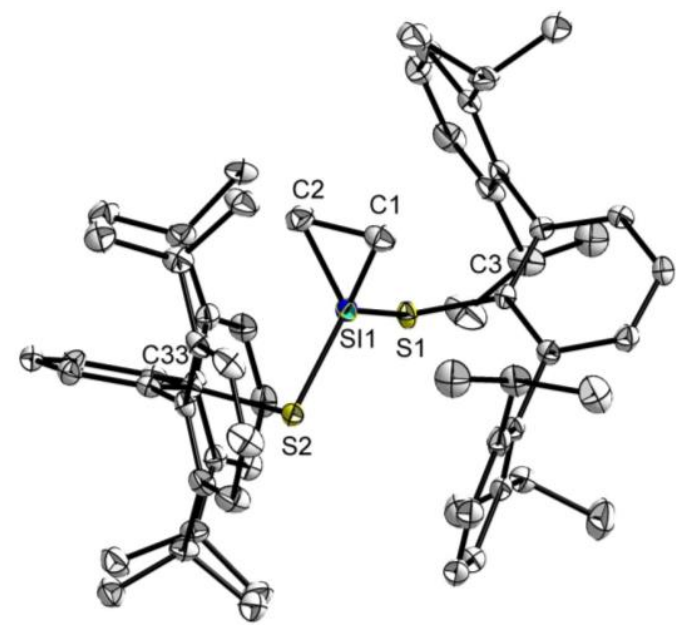

Figure 1. Thermal ellipsoid plot (50\%) of one of the two crystallographically independent molecules of 4 . Hydrogen atoms and cocrystallized toluene molecules are not shown. Selected bond distances $(\AA)$ and angles (deg.): C1-C2, 1.569(2); C1-Si1, 1.8399(17); C2-Si1, 1.8332(16); Si1-S1, 2.1181(5); Si1-S2, 2.1167(5); $\mathrm{S}_{1}-\mathrm{C}_{3}$, 1.7911(15); S1-C 33, 1.7953(15); C1-Si1-C2, 50.58(7); C1-C2Si1, 64.94(8); C2-C1-Si1, 64.49(8), S1-Si1-S2, 116.49(2).

The mechanism for the reaction of $\mathbf{1}$ and $\mathbf{2}$ with ethylene (Scheme 2) was studied computationally (PBE1PBE/TZVP level) ${ }^{8}$ using a model system in which the bulky $\mathrm{Ar}^{\mathrm{Me}} 6$ and $\mathrm{Ar}^{\mathrm{Pr}^{\mathrm{i}}}$ substituents were replaced with phenyl $\left(\mathrm{Ph}=\mathrm{C}_{5} \mathrm{H}_{6}\right)$ to reduce computational costs; our previous studies on related systems have shown that this simplification is well justified. 9 The optimized geometries of $\mathrm{Si}(\mathrm{SPh})_{2}(6)$ and $(\mathrm{PhS})_{2} \mathrm{SiCH}_{2} \mathrm{CH}_{2}(7)$ reproduce well most of the experimental structural parameters of $\mathbf{1}$ and $\mathbf{2}$. For 
example, the calculated Si-S distances are 2.160 $\AA$ and $2.149 \AA$ for 6 and 7 , respectively, whereas the Si$C$ bonds in 7 are each $1.846 \AA$ long, and therefore very similar to those in the experimentally characterized siliranes (see above). The calculated CSi-C angle in $7\left(50.4^{\circ}\right)$, is a perfect match with the experimental data for $\mathbf{4}$, but the theoretically predicted S-Si-S angle in $7\left(105.2^{\circ}\right)$ differs significantly from the crystallographically determined structure, mainly because the simplified model system experiences low steric repulsion and dispersion effects between its phenyl groups. ${ }^{6}$

The transition state for the association of ethylene with 6 (6-TS) was located computationally and it shows that the olefin approaches the silylene in an asymmetric fashion from one side of the S-Si-S plane ( $\mathrm{Si}-\mathrm{C}$ distances of 2.309 and $2.630 \AA$ ). The activation energy $\left(\Delta G^{\ddagger}\right)$ calculated for this process is $54 \mathrm{~kJ} \mathrm{~mol}^{-1}$, whereas the calculated $\Delta \mathrm{H}_{\mathrm{assn}}$ and $\Delta \mathrm{G}_{\mathrm{assn}}$ for the formation of 7 are $-68 \mathrm{~kJ}$ and $-24 \mathrm{~kJ} \mathrm{~mol}^{-1}$, respectively, in very good agreement with the numbers obtained from the Van't Hoff analysis.

The bonding interactions within 6-TS were analyzed with the ETS-NOCV approach that combines the extended transition state method for energy decomposition analysis (EDA) with the theory of natural orbitals of chemical valence. ${ }^{10}$ The results show that the transition state can be described as a synergic donor-acceptor interaction between $\mathbf{6}$ and ethylene wherein the HOMO of the silylene (silicon-sulfur bond lone-pair combination) interacts with the LUMO ( $\pi^{*}$-orbital) of ethylene and vice versa (Figure 2, left). The effect of these interactions on the deformation density (the density of 6-TS minus the sum of separate densities for $\mathbf{6}$ and ethylene) shows clearly the transfer of electrons (from green to yellow) to generate the Si-C bonding interaction (Figure 2, middle). It is of interest to note that when the geometry of 6-TS changes to that of the complex 7 , the key orbital interactions are effectively 'reversed' in the process: for 7 , the HOMO is a bonding combination between the LUMOs of ethylene and 6, whereas the HOMO-7 orbital involves an interaction between the HOMOs of the corresponding molecular fragments (Figure 2, right).

The reversible reactions of $\mathbf{1}$ and $\mathbf{2}$ with ethylene are the first such examples for a two-coordinate group 14 element carbene analogue and, apart from the aforementioned distannynes and silylenephosphine complex, are the only instances of reversible complexation of olefins at room temperature by a main group element compound. However, a reversible reaction with an unsaturated $\mathrm{C}-\mathrm{C}$ multiple-bonded compound has been observed for the reaction of the stannylene $\mathrm{Sn}\left\{\mathrm{CH}\left(\mathrm{SiMe}_{3}\right)_{2}\right\}_{2}$ with the strained cyclic acetylene

$\mathrm{SCH}_{2} \mathrm{CMe}_{2} \mathrm{C} \equiv \mathrm{CCMe}_{2} \mathrm{CH}_{2}$, which affords the first example of a stannacyclopropene. In this case, the strained cis-bent structure of the alkyne moiety promotes the reactivity, as well as the reversibility of the overall reaction. ${ }^{11}$

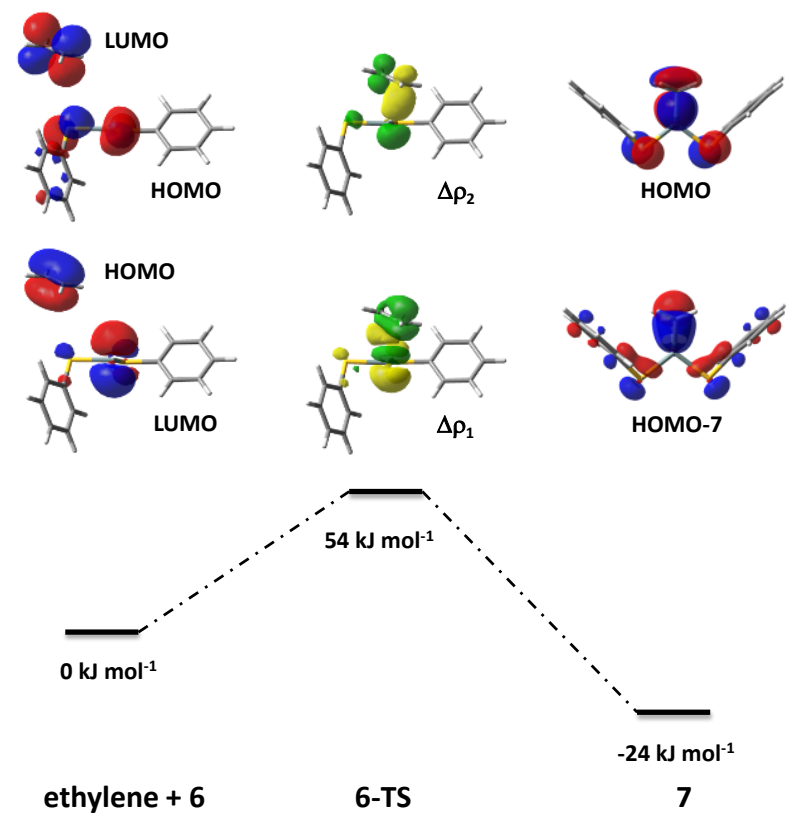

Figure 2. Top: the most important $\mathrm{Si}-\mathrm{C}$ bonding orbital interactions between $6\left(\mathrm{Si}(\mathrm{SPh})_{2}\right)$ and ethylene (left), and in $7\left((\mathrm{PhS})_{2} \mathrm{SiCH}_{2} \mathrm{CH}_{2}\right)$, right $)$ along with the two most important NOCV deformation densities $\Delta \rho$ of 6TS showing the charge flow to form $\mathrm{Si}-\mathrm{C}$ bonding interactions (middle). Bottom: calculated energy profile for the reaction of ethylene with $\mathbf{6}$ to afford the silirane 7 .

We note that ethylene is now known to react under ambient conditions with an ever-increasing number of classes of stable main-group compounds without external stimuli, such as photolysis. These include disilynes, ${ }^{12}$ digermynes, ${ }^{3}$ frustrated Lewis-pair borane-phosphine molecules, ${ }^{13}$ silylenes, ${ }^{14}$ silylene precursors, ${ }^{7 \mathrm{k}}$ and digallenes, ${ }^{15}$ but reversibility in ethylene binding, which is key for the development of possible catalysts, remains rare.3,4 Further studies of the electronic factors that govern the reversibility of ethylene complexation by silylenes and their heavier group 14 element congeners are in hand. 


\section{ASSOCIATED CONTENT}

Supporting Information. Full experimental, spectroscopic, and computational details as well as CIFs for compounds $\mathbf{4}$ and $\mathbf{5}$.

\section{AUTHOR INFORMATION}

E-mail for P.P.P.: pppower@ucdavis.edu

E-mail for H. M. T.: heikki.m.tuononen@jyy.fi

\section{ACKNOWLEDGEMENTS}

We are grateful to the U. S. Department of Energy (DEFGo2-07ER46475; P. P. P.), the Academy of Finland (H. M. T.) and the Technology Industries of Finland Centennial Foundation (A. M.) for support of this work. F. L. thanks the Alexander von Humboldt Foundation for a Feodor Lynen Research Fellowship.

\section{REFERENCES}

1. (a) Gaspar, P. P.; West, R. In The Chemistry of Organic Silicon Compounds; Rappoport, Z., Apeloig, Y., Eds.; Wiley: Chichester, 1998. (b) Weidenbruch, M. Organometallics. 2003, 22, 4348. (c) Hill, N. J.; West, R. J. Organomet. Chem. 2004, 689, 4165. (d) Mizuhata, Y.; Sasamori, T.; Tokitoh, N. Chem. Rev. 2009, 109, 3479. (e) Yao, S.; Xiong, Y.; Driess, M. Organometallics. 2011, 30, 1748. (f) Sen, S. S.; Khan, S.; Nagendran, S.; Roesky, H. W. Acc. Chem. Res. 2012, 45, 578.

2. (a) Gaspar, P. P.; Holter, D.; Knieczny, S. Acc. Chem. Res. 1987, 20, 329. (b) Boudjouk, P.; Samarweera, U.; Sooryakumarai, S.; Chrusciel, J.; Anderson, K. R. Angew. Chem. Int. Ed. Engl. 1988, 27, 1355. (c) Boudjouk, P.; Black, E.; Kumarathasan, R. Organometallics. 1991, 10, 2095. (c) Pal, D. H.; Xiao, M.; Chiang, M. Y.; Gaspar, P. P. J. Am. Chem. Soc. 1991, 113, 1281. (d) Zhang, S.; Wagenseller, P. E.; Conlin, R. T. J. Am. Chem. Soc. 1991, 113, 42781 .

3. Peng, Y.; Ellis, B. D.; Wang, X.; Fettinger, J. C.; Power, P. P. Science. 2009, 325, 1668.

4. Rodriguez, R.; Gau, D.; Kato, T.; Saffon-Merceron, N.; De Cózar, A.; Cossió, F. P.; Baceiredo, A. Angew. Chem. Int. Ed. 2011, 50, 10414 .

5. Rekken, B. D.; Brown, T. M.; Fettinger, J. C.; Tuononen, H. M.; Power, P. P. J. Am. Chem. Soc. 2012, 134, 6504.

6. Rekken, B. D.; Brown, T. M.; Fettinger, J. C.; Lips, F.; Tuononen, H. M.; Herber, R. H.; Power, P. P. J. Am. Chem. Soc. 2013, 135, 10134.

7. (a) Delker, G. L.; Wang, Y.; Stucky, G. D.; Lamber, T. R. L.; Haas, C. K.; Seyferth, D. J. Am. Chem. Soc. 1976, 98, 1779. (b) Ishikawa, M.; Matsuzawa, S.; Sugisawa, H.; Yano, F.; Kamitori, S.; Higuchi, T. J. Am. Chem. Soc. 1985, 107, 7706. (c) Ando, W.; Fujita, M.; Yoshida, H.; Sekiguchi, A. J. Am. Chem. Soc. 1988, 110, 3310. (d) Suzuki, H.; Tokitoh, N.; Okazaki, R. J. Am. Chem. Soc. 1994, 116, 11572. (e) Suzuki, H.; Tokitoh, N.; Okazaki, R. Bull. Chem. Soc. Jpn. 1995, 68, 2471. (f) Ando, W.; Shiba, T.; Hidaka, T.; Morihashi, O.; Kikuchi, J. J. Am. Chem. Soc. 1997, 119, 3629. (g) Kira, M.; Ishida, S.; Iwamoto, T.; Kabuto, C. J. Am. Chem. Soc. 1999, 121, 9722. (h) Klapötke, T. M.; Vasisht, S. K.; Mayer, P. Z. Anorg. Allg. Chem. 20o9, 635, 2447. (i) Pichaandi, K. R.; Mague, J. T.; Fink, M. J. J. Organomet. Chem. 2011, 696, 1957. (j) Cho, H.
M.; Boh, K.; Park, K.; Park, S. H.; Lim, Y. M.; Lee, M. E.; Choi, M.G.; Lee, K. M. Organometallics. 2012, 31, 5527.

8. (a) Perdew, J. P.; Burke, K.; Ernzerhof, M. Phys. Rev. Lett. 1996, 77, 3865. (b) Perdew, J. P.; Ernzerhof, M.; Burke, K. J. Chem. Phys. 1996, 105, 9982. (c) Perdew, J. P.; Burke, K.; Ernzerhof, M. Phys. Rev. Lett. 1997, 78, 1396. (d) Adamo, C.; Barone, V. J. Chem. Phys. 1999, 110, 615. (e) Schaefer, A.; Huber, C.; Ahlrichs, R. J. Chem. Phys. 1994, 100, 5829.

9. Brown, Z. D.; Vasko, P.; Erickson, J. D.; Fettinger, J. C.; Tuononen, H. M.; Power, P. P. J. Am. Chem. Soc. 2013, 135, 6257. 10. (a) Mitoraj, M.; Michalak, A. J. Mol. Model. 2007, 13, 347. (b) Michalak, A.; Mitoraj, M.; Ziegler, T. J. Phys. Chem. A 2oo8, 112, 1933. (c) Radón, M. Theor. Chem. Acc. 20o8, 120, 337. (d) Morokuma, K. J. Chem. Phys. 1971, 55, 1236. (e) Kitaura, K.; Morokuma, K. Int. J. Quantum. Chem. 1976, 10, 325. (f) Ziegler, T.; Rauk, A. Theoret. Chim. Acta 1977, 46, 1.

11. Sita, L. R.; Bickerstaff, R. D. J. Am. Chem. Soc. 1988, 110, 5208.

12. (a) Kinjo, R.; Ichinohe, M.; Sekiguchi, A.; Takagi, N.; Sumitomo, M.; Nagase, S. J. Am. Chem. Soc. 2007, 129, 7766. (b) Han, J. S.; Sasamori, T.; Mizuhata, Y.; Tokitoh, N. J. Am. Chem. Soc. 2010, 132, 2546.

13. McCahill, J. S. J.; Welch, G. C.; Stephan, D. W. Angew.

Chem. Int. Ed. 2007, 46, 4968.

14. Ishida, S.; Iwamoto, T.; Kira, M. Heteroatom. Chem. 2011, 22, 432 .

15. Caputo, C. A.; Zhu, Z.; Brown, Z. D.; Fettinger, J. C.; Power, P. P. Chem. Commun. 2011, 47, 7506. 